\title{
Analysis of Land Use Change in Bantul Regency Using Geoprocessing Technique
}

\author{
Tirsa Ninia Lina ${ }^{1}$, Matheus Supriyanto Rumetna ${ }^{2}$ \\ \{tirsawp@gmail.com ${ }^{1}$, matheus.rumetna@gmail.com ${ }^{2}$ \} \\ Faculty of Computer Science, Victory University of Sorong, Basuki Rahmat Km. 11.5 Sorong City ${ }^{1,2}$
}

\begin{abstract}
Today, the land has an important and strategic role in development. Increase in population from year to year causes an increase in the need for land use, while the form and extent of land are relatively fixed. Bantul Regency is part of D.I.Yogyakarta Province which experienced changes in land use and utilization. This research was aimed to provide information about land use change in Bantul regency year 2011-2015. This research used Geographic Information System (GIS) by using Open Source Quantum GIS software. The method used in this research was data collection in the form of survey and interview, and data analysis using geoprocessing technique to Bantul Regency administration map, land use map of Bantul Regency in 2011 and 2015, and the map of change. The result of this research was information about land use change that happened in Bantul regency.
\end{abstract}

Keywords: Geographic Information System, Land Use, Spatial Data, Quantum GIS, Geoprocessing.

\section{Introduction}

Land has an important and strategic role in development, especially in the present. Increase in population from year to year leads to an increase in the population's need for land use, while the form and size of land are relatively constant. With the increasing population's need for land use, it can lead to land issues related to increased demand for land use [1][2][3], among others :

a. Decreased in the land for agricultural activities, which are transformed into settlements, industrial or other non-agricultural land uses.

b. The emergence of new areas that are utilized for settlements that are unfit for habitation and not by the spatial plan of the region, for example on the river edge, in areas of steep slopes prone to landslides.

c. The appearance of productive agricultural land that was previously productive as a result of the sporadic growth of settlements on agricultural land, thus disrupting the irrigation and lack of incentives for farmers.

d. Decreased in the environmental quality due to the use of land that is less attention to the balance of nature and can lead to various natural disasters, such as flood, landslide, and lack of clean water.

e. The increasing amount of waste caused by various land uses that can cause pollution and disrupt various aspects of human life and other living things 
Bantul Regency is part of Yogyakarta Special Province (DIY) consisting of 17 subdistricts and 75 village /kelurahan, with an area of 51,295.44 Hectare. The area of Bantul Regency lies between $7^{\circ} 44^{\prime} 04$ "- $8^{\circ} 00^{\prime} 27^{\prime \prime}$ South Latitude and $110^{\circ} 12$ '34 "- 110 31' 08" East Longitude, with regional administrative boundaries as follows [4][5] :

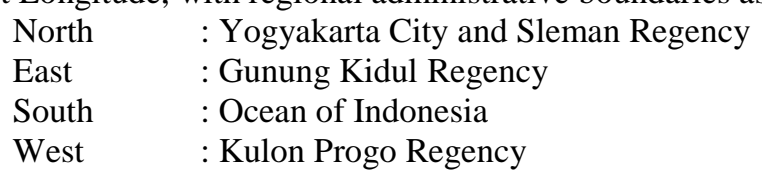

Bantul Regency also experienced problems of land use and utilization. For example the use of land for industrial areas, fixed emplacement, housing, open land, historic sites, ponds, rice fields, and so on. With so many problems of land, the government is required to arrange and manage and can minimize the conflict of use and utilization of land for the benefit of both present and future, so that the realization of sustainable and optimal use and utilization of land in Bantul Regency.

Open Source software in the field of GIS has been widely used and has been proven to deliver results with high accuracy [6][7][8][9][10][11][12][13][14][15][16][17]. Some GIS software has been widely used, one of them is Quantum GIS [18][19]. Geoprocessing is one of the techniques contained in Quantum GIS that can be used to analyze these problems. This study is aimed to provide information on land use changes that occurred in 2011 and 2015 and the development of land use in Bantul District.

\section{Method}

The research method used in the analysis of land use change in Bantul Regency was divided into data collection and data analysis.

\subsection{Data Collection}

The method used in data collection was survey and interview. The survey was conducted to see the area experiencing land use change in Bantul regency. The interview was conducted by meeting with the Regional Office of the National Land Agency of DIY to obtain data related to land use in Bantul District. The data obtained in the form of administrative data of Bantul Regency, Bantul Regency land use data in 2011 and 2015, and data changes.

\subsection{Data Analysis}

Data analysis was done using geoprocessing technique. The map data used include the administrative map of Bantul Regency, land use map of Bantul regency in 2011, land use map of Bantul Regency in 2015, and map of change. 


\section{Result and Discussions}

\subsection{Implementation of Geoprocessing Techniques}

Prior to implementing geoprocessing techniques, there were several thematic maps that need to be prepared in advance: Administration Map of Bantul Regency, Land Use Map of Bantul Regency Year 2011, Land Use Map of Bantul Regency Year 2015, and Map of Change. The prepared files then would be processed using one of the geoprocessing functions of intersect [20][21][22][23], as follows:

a. Map of Change Administration

b. The intersect function would be done by combining administrative map files and map changes. The intersect results of both files would result in Change Administration Map (Fig 1a).

c. Land Use Map of Bantul Regency Year 2011-2015

d. The intersect function would be done by combining the land use map file in 2011 and land use map of 2015. The intersect result of the two files would produce the Land Use Map of Bantul Regency Year 2011-2015 (Fig.1b).

e. Land Use Change Map of Bantul Regency Year 2011-2015

f. The result of first intersecting was Fig. 1a would then be merged with the second intersect of Fig. 1b. The result was a Land Use Change Map of Bantul Regency Year 2011-2015 (Fig 2). In Fig. 2 visible changes that occurred in the year 20112015.

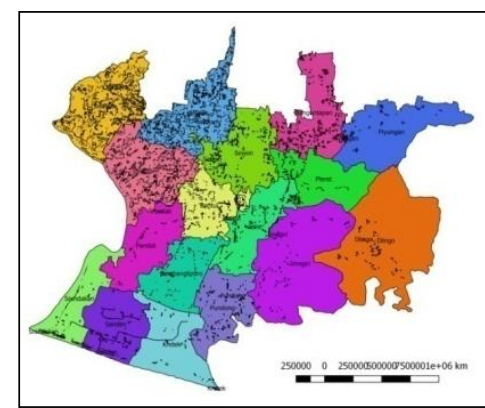

(a)

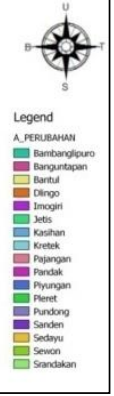

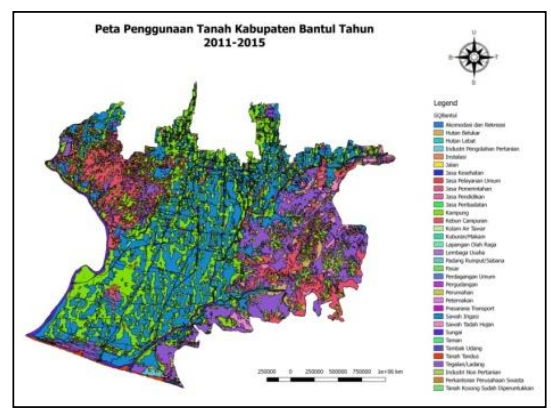

(b)

Fig. 1. Change Administration Map (a), Land Use Map of Bantul Regency Year 2011-2015 (b). 


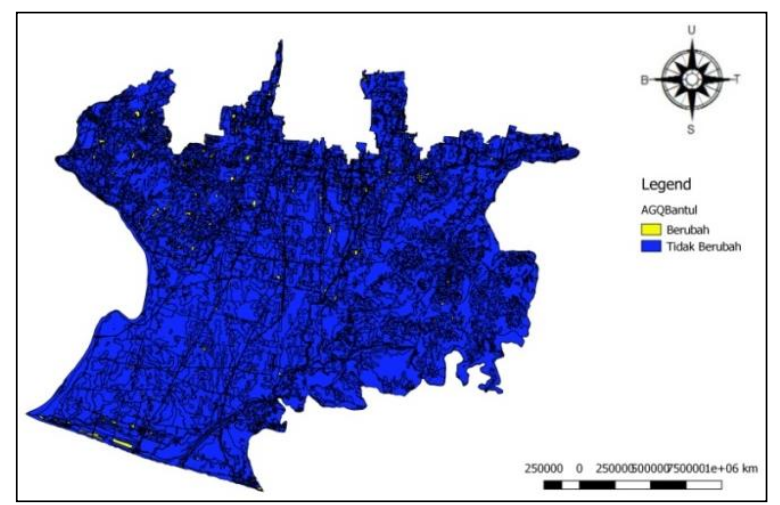

Fig. 2. Land Use Change Map of Bantul Regency Year 2011-2015.

\subsection{Analysis of Land Use}

\subsubsection{Land Use Conditions}

Land use is a series of activities to manage the allocation, use, and inventory of land on a planned and regular basis to obtain benefits that are sustainable, optimal, harmonious, and balanced for the greatest prosperity of the people and the state. One element in land use is the use of land. Before conducting land use analysis, land use in 2011 and 2015 in Bantul Regency should be known first. The largest land use in Bantul District in 2011 was the use of land for irrigated rice field 2x rice+secondary crop/year, ie 19,934.69 Hectares or $38.86 \%$ of Bantul Regency, while the smallest land use was land use for historic sites, covering 0.7 Hectares or $0.001 \%$ of the total area [5]. The largest land use in Bantul Regency in 2015 was still the same as the land use in Bantul regency in 2011, i.e. the use of land for irrigated rice field $2 \mathrm{x}$ rice + secondary crop / year, but in 2015 the area was reduced, which was originally $19,934.69$ Hectares reduced to $14,539.85$ Hectares or $28.35 \%$ of the area, while the smallest land use was land use for historic sites, which was 0.7 Hectares or equal to $0.001 \%$ of the total area and the area is unchanged [5].

\subsubsection{Analysis of Land Use Change}

Based on land use conditions in 2011 and 2015, it could be seen that land use was changing. These changes occurred in some land uses, such as in various types of industrial land use, fixed emplacement, densely populated, mixed gardens, meadow, sand, rare housing, densely populated, mixed farms, irrigated rice field $2 \mathrm{x}$ rice + secondary crop / year, bushes, fish ponds, temporary open land and moor / fields. Changes in land use can be seen in Table 1.

Changes in land use from 2011 to 2015 had experienced an increase in the number of areas, and some have reduced (-) the amount of land use. The dominant land use in 2011 and 2015 could be seen changes in land use in the form of irrigated rice field $2 \mathrm{x}$ rice + secondary crop/year experienced a reduction of 5,394.84 Hectares or equal to $10.52 \%$, while the change of land use in the form of densely populated has an area of 1135, 00 Hectares or equal to $2.21 \%$. 
Table 1. Land Use Change of Bantul Regency in $2011-2015$.

\begin{tabular}{|c|c|c|c|c|c|c|}
\hline \multirow[b]{2}{*}{ No. } & \multirow[b]{2}{*}{ Land Use } & \multicolumn{2}{|c|}{ Area (Ha) } & \multicolumn{3}{|c|}{ Land Use Change } \\
\hline & & $\begin{array}{c}\text { The year } \\
2011\end{array}$ & $\begin{array}{c}\text { The year } \\
2015\end{array}$ & Area (Ha) & $\%$ Change & $\begin{array}{c}\text { Average/year } \\
\text { (Ha) }\end{array}$ \\
\hline 1 & Industrial & 136,62 & 154,15 & 17,53 & 0,03 & 4,38 \\
\hline 2 & $\begin{array}{l}\text { Temporary } \\
\text { Emplacement }\end{array}$ & 89.91 & 89.91 & 0.00 & 0.00 & 0.00 \\
\hline 3 & Fixed Emplacement & 876,68 & 876,90 & 0,22 & 0,00 & 0,05 \\
\hline 4 & Gymnasium & 27,66 & 27,66 & 0,00 & 0,00 & 0,00 \\
\hline 5 & Sand & 108,79 & 108,79 & 0,00 & 0,00 & 0,00 \\
\hline 6 & Undergrowth Forest & 432,47 & 432,47 & 0,00 & 0,00 & 0,00 \\
\hline 7 & Dense Forest & 12,96 & 12,96 & 0,00 & 0,00 & 0,00 \\
\hline 8 & Homogenous Forest & 57,83 & 57,83 & 0,00 & 0,00 & 0,00 \\
\hline 9 & Road & 340,57 & 340,57 & 0,00 & 0,00 & 0,00 \\
\hline 10 & Dense Village & $10.165,10$ & $11.300,10$ & $1.135,00$ & 2,21 & 283,75 \\
\hline 11 & Mixed Gardens & $7.311,39$ & $7.310,06$ & $-1,32$ & 0,00 & $-0,33$ \\
\hline 12 & Fresh Water Pond & 86,25 & 86,25 & 0,00 & 0,00 & 0,00 \\
\hline 13 & Grave/Cemetery & 133,63 & 133,63 & 0,00 & 0,00 & 0,00 \\
\hline 14 & Field (Sport) & 78,54 & 78,54 & 0,00 & 0,00 & 0,00 \\
\hline 15 & Mangrove & 14,58 & 14,58 & 0,00 & 0,00 & 0,00 \\
\hline 16 & Meadow & 30,82 & 30,91 & 0,09 & 0,00 & 0,02 \\
\hline 17 & Sand & 155,49 & 157,28 & 1,79 & 0,00 & 0,45 \\
\hline 18 & Open Mining & 2,97 & 2,97 & 0,00 & 0,00 & 0,00 \\
\hline 19 & Rare Housing & 18,17 & $2.418,17$ & $2.400,00$ & 4,68 & 600,00 \\
\hline 20 & Solid Housing & 243,36 & $1.343,36$ & $1.100,00$ & 2,14 & 275,00 \\
\hline 21 & Mixed Farm & 52,50 & 53,33 & 0,83 & 0,00 & 0,21 \\
\hline 22 & $\begin{array}{l}\text { Irrigated Rice Field } \\
2 x \text { Rice+Secondary } \\
\text { Crop/Year }\end{array}$ & $19.934,69$ & $14.539,85$ & $-5.394,84$ & $-10,52$ & $-1.348,71$ \\
\hline 23 & Rain-fed Field & $1.428,57$ & $1.428,57$ & 0,00 & 0,00 & 0,00 \\
\hline 24 & Bushes & $1.054,81$ & $1.047,13$ & $-7,67$ & $-0,01$ & $-1,92$ \\
\hline 25 & River & 921,65 & 921,65 & 0,00 & 0,00 & 0,00 \\
\hline 26 & Fish Pond & 26,67 & 47,38 & 20,71 & 0,04 & 5,18 \\
\hline 27 & $\begin{array}{l}\text { Temporary Open } \\
\text { Land }\end{array}$ & 39,72 & 0,00 & $-39,72$ & $-0,08$ & $-9,93$ \\
\hline 28 & Field & $7.512,34$ & $8.279,74$ & 767,40 & 1,50 & 191,85 \\
\hline 29 & Historical Sites & 0,70 & 0,70 & 0,00 & 0,00 & 0,00 \\
\hline & Total & $51.295,44$ & $51.295,44$ & $10.887,11$ & 21,22 & $2.721,78$ \\
\hline
\end{tabular}

The increase in land use occurred in various industrial uses, fixed emplacements, dense villages, meadow, sand, rare housing, dense housing, mixed farms, fish pond, and field. Area reductions occurred in the land use of mixed garden, irrigated rice field $2 x$ rice + secondary crop/year, bushes, and temporary open land. 


\section{Conclusion}

With this research, the researchers concluded that:

a. The dominant land use in Bantul Regency in 2011 was irrigated rice field $2 \mathrm{x}+$ secondary crop/year with an area of $19,934.69 \mathrm{Ha}$ or $38.86 \%$ of the total area of Bantul Regency and densely populated area of $10,165.10 \mathrm{Ha}$ or $19.82 \%$ of the total area of Bantul Regency.

b. The dominant land use in Bantul Regency in 2015 was irrigated rice field 2x rice + secondary crop/year with an area of $14,539.85 \mathrm{Ha}$ or equal to $28.35 \%$ of the total area of Bantul regency and densely populated area of $11,300.10 \mathrm{Ha}$ or equal to $22.03 \%$ of the total area of Bantul Regency.

c. Based on the dominant land use in 2011 and 2015, it could be seen that land use change in the form of irrigated rice field $2 \mathrm{x}$ rice + secondary crop/year experienced a reduction of 5,394.84 Ha or $10.52 \%$, while the change of land use in the form of densely populated kampung has an area of $1,135,00 \mathrm{Ha}$ or equal to $2.21 \%$.

d. The number of changes in land use or commonly referred to land conversion from agriculture to non-agriculture indicates the tendency of Bantul regency community especially in urban areas that change from agrarian to nonagrarian patterns such as in industry, trade, and services. Also, the need for land as settlements also increased with the increasing population in Bantul District.

\section{References}

[1] H. Xie, P. Wang, and H. Huang, "Ecological risk assessment of land use change in the poyang lake eco-economic zone, China," Int. J. Environ. Res. Public Health, vol. 10, no. 1, pp. 328-346, 2013.

[2] H. Prasetyo and M. Thohiron, "Aplikasi SIG dalam penilaian status kerusakan tanah untuk produksi biomassa di Kabupaten Tuban, Jawa Timur," J-Pal, vol. 4, no. 1, pp. 63-68, 2013.

[3] M. S. Rumetna, "Pemanfaatan Sistem Informasi Geografi Untuk Deteksi Daerah Rawan Longsor Di Kecamatan Sidomukti, Salatiga," KUADAS, vol. 1, no. 1, pp. 11-23, 2018.

[4] BPS Kabupaten Bantul, Bantul Dalam Angka 2015 - Katalog BPS 1102001.3402. 2015.

[5] Kantor Wilayah Badan Pertanahan Nasional Daerah Istimewa Yogyakarta, "Kantor Wilayah Badan Pertanahan Nasional Daerah Istimewa Yogyakarta," 2015.

[6] T. Baroš and T. Stojanović, "Geographic Information System (GIS) in Mapping of Mine Suspected Area in the Republic of Serpska," Glob. J. Sci. Front. Res. H Environ. Earth Sci., vol. 15, no. 3, 2015.

[7] P. K. Patra, C. Pradhan, and A. Tripathy, "An Intelligent Framework For Distributed Query Optimization Of Spatial Data In Geographic Information Systems," Int. J. Comput. Sci. Netw. Secur., vol. 8 , no. 5, pp. 36-43, 2008.

[8] M. M. Sardadi, M. Rahim, Z. Jupri, and D. bin Daman, "Quadtree Spatial Indexing Use to Make Faster Showing Geographical Map in Mobile Geographical Information System Technology Using an Oracle 10g Application Server and MapViewer Applications," Int. J. Comput. Sci. Netw. Secur., vol. 8, no. 10, pp. 253-262, 2008.

[9] M. Khalesian, P. Pahlavani, and M. R. Delavar, "A GIS-based Traffic Control Strategy Planning at Urban Intersections," Int. J. Comput. Sci. Netw. Secur., vol. 9, no. 1, pp. 166-174, 2009.

[10] Y. Dakroury, I. El-ghafar, and A. Tammam, "Protecting GIS Data Using Cryptography and Digital Watermarking," Ijcsns, vol. 10, no. 1, pp. 75-84, 2010.

[11] W. Alsabhan, "Real-Time Mobile GIS Prototype: Design, Architecture, and Usability Study," 
Int. J. Comput. Sci. Netw. Secur., vol. 10, no. 2, pp. 260-266, 2010.

[12] M. Zouiten, M. Harti, and C. Nejjari, "An Architecture and An Ontology-Based Context Model for GIS Health Monitoring and Alerting: Case of Tuberculosis in Morocco," Int. J. Comput. Sci. Netw. Secur., vol. 10, no. 11, pp. 218-222, 2010.

[13] T. R. Soomro, "Non-Traditional Security and Role of GIS," Int. J. Comput. Sci. Netw. Secur., vol. 11, no. 11, pp. 1-7, 2011.

[14] S. Sonti, "Application of Geographic Information System (GIS) in Forest Management," Geogr. Nat. Disasters, vol. 5, no. 3, pp. 1-5, 2015.

[15] P. C. Acquah, J. N. Asamoah, and D. D. Konadu, "Introduction of Geographical Information Systems (GIS) in Technical University Education in Ghana: Challenges and the Way Forward," Rev. Int. Geogr. Educ. Online, vol. 7, no. 2, pp. 207-220, 2017.

[16] A. R. As-syakur, I. W. Suarna, I. W. Rusna, and I. N. Dibia, "Pemetaan Kesesuaian Iklim Tanaman Pakan Serta Kerentanannya Terhadap Perubahan Iklim Dengan Sistem Informasi Geografi (SIG) di Provinsi Bali," Pasutra, vol. 1, no. 1, pp. 9-15, 2011.

[17] T. N. Lina, E. Sediyono, and S. Y. J. Prasetyo, "Analisis Pemanfaatan Kawasan Wilayah Pesisir Menggunakan Local Indicators of Spatial Association (Lisa) (Studi Kasus : Kabupaten Kulon Progo)," SIMETRIS, vol. 8, no. 2, pp. 781-790, 2017.

[18] T. N. Lina, "Analisis Pemanfaatan Kawasan Wilayah Pesisir Kabupaten Kulon Progo berdasarkan Pemilikan Tanah menggunakan Teknik Geoprocessing," KUADAS, vol. 1, no. 1, pp. 2437, 2018.

[19] S. Hussein and Werdiningsih, "Pemanfaatan Sistem Informasi Geografis (SIG) berbasis Open Source untuk Analisis Kerentanan Air Permukaan SubDAS Blongkeng," Teknol. Inf. dan Komun., vol. 2012, no. Sentika, pp. 1-6, 2012.

[20] B. Hofer, "Geospatial Cyberinfrastructure and Geoprocessing Web-A Review of Commonalities and Differences of E-Science Approaches," ISPRS Int. J. Geo-Information, pp. 749$765,2013$.

[21] B. Marjuki, Sistem Informasi Geografi Menggunakan QGIS 2.0.1..pdf. 2014.

[22] H. L. Maranhão and L. . Sant'ana, "Utilization of Geoprocessing for Environmental Studies," in Proceedings of the International Academy of Ecology and Environmental Sciences, 2016, vol. 6, no. 3, pp. 62-66.

[23] M. S. Rumetna, E. Sediyono, and K. . Hartomo, "Analisis Perubahan Tata Guna Lahan di Kabupaten Bantul Menggunakan Metode Global Moran's I,” J. Buana Inform., vol. 8, no. 4, pp. 225$233,2017$. 